\title{
Euskal Herrian bizi diren magrebtarren eta latinoame- rikarren akulturazio-prozesua eta osasun psikologikoa
}

\author{
Edurne Elgorriaga, Ainara Arnoso, Cristina Martínez-Taboada, \\ Eneritz Balerdi eta Maddi Berasategi \\ Unibertsitateko irakasleak (Psikologia Fakultatea, UPV/EHU) eta psikologoak
}

Ikerlan honetan, Euskal Herrian bizi diren etorkinen hautemandako estresa eta ongizate-maila eta aldagai horien aurrekariak neurtzen dira, generoaren eta jatorriaren arabera egon daitezkeen desberdintasunak kontuan hartuz. 405 emakume eta gizon etorkin elkarrizketatu ziren bai Latinoamerikakoak bai Magrebekoak, eta 306 emakume eta gizon euskaldun. Emaitza nabarmengarrienek adierazten dute estresa eta ongizate-maila ertainak direla, eta Magrebeko etorkinek Latinoamerikakoekin eta euskaldunekin konparatuta estres gehiago eta ongizate gutxiago adierazten dutela. Horrela, Magrebeko etorkinekin baieztatzen da akulturazioaren estresaren hipotesia eta Latinoamerikako etorkinen egoera esplikatzeko egokiagoa da atzerritar osasuntsuaren paradoxa. Azkenik, ikusten da estresaren eta ongizatearen aurrekariak desberdinak direla jatorri kulturalaren arabera.

GAKO-HITZAK: Akulturazio-estresa • Ongizatea · Immigrazioa · Generoa · Distantzia kulturala.

\section{Latin American and Maghrebian aculturation process in the Basque Country and its influence on mental health}

The aim of this study is to analyze the level and predictive factors of perceived stress and life satisfaction of immigrants actually live in the Basque Country, and to analyse the influence of gender and cultur origen. The sample is composed of 405 women and men from Latin America and the Maghreb and 306 natives women and men. Results show moderate levels of stress and life satisfaction. Immigrants from the Maghreb show greater stress and less satisfaction than Latin American immigrants and natives. The acculturation stress hypothesis explains the stress and satisfaction levels of Maghrebian immigrants, and the health immigrant paradox was plausible in the case of Latin American immigrants. Finally, the predictors of stress and satisfaction was different in each group. distance.

KEY WORDS: Aculturation stress · Satisfaction · Immigration · Gender · Cultur 


\section{Sarrera}

Azkeneko urteetan Espainiako Estatura iristen diren pertsona atzerritarren kopuruak behera egin du: 2008. urtean 599.074 pertsona ailegatu baziren, 2014an 305.454 pertsona izan ziren ailegatu zirenak (INE, 2014). Hala ere, etorkinen presentzia handia da, azken datuen arabera, Espainiako Estatuan 4.549.858 pertsona atzerritar bizi dira eta horietatik 142.392 pertsona Euskal Autonomia Erkidegoan daude eta 54.431 Nafarroan (INE, 2017).

Beren jatorrizko herrialdetik lekua aldatu eta beste testuinguru batean kokatzen diren pertsonek gizarte berrira trantsizio eta egokitzapen aldi bat hasten dute, akulturazio-prozesua ere deitu zaiona (Berry, 1997). Prozesu horretan zenbait aldaketa gertatzen dira (Organista, Organista eta Kurasaki, 2002), hala nola etena jatorrizko herrialdearekin (Achotegui, 2004), gizarte hartzailearen kultura eta kodigoekin kontaktua eta horien ikaskuntza (Ward eta Kennedy, 1999), oinarrizko beharrak asetzeko errekurtsoak bilatzeko premia eta talde arteko erlazioen ulermen berria (Prilleltensky, 2008). Aldaketa eta egoera berri horietan sor daitezkeen arazoek estres-maila altua edota ongizate eta osasun mentaleko arazoak sor ditzakete, pertsonak ez badu taldeko eta banakako errekurtso nahikorik arazoari aurre egiteko (Ward, Bochner eta Furnham, 2001).

\section{Akulturazio-prozesua eta osasun psikologikoaren ikerketa eta teoriak}

Akulturazio-prozesuaren eta osasun psikologikoaren arteko erlazioa aztertu duten hainbat ikerketa ondorio ezberdinetara iritsi dira. Hala, ikerketa-lerro batek atzerritar osasuntsuaren paradoxaren hipotesia babesten du (Markides eta Coreil, 1986). Autore horiek defendatzen dutenaren arabera, biztanleria atzerritarraren osasun fisikoa eta mentala berdina edo hobeagoa da biztanleria autoktonoarekin alderatuta edota herrialde hartzailean jaiotako aberkideekin alderatuta, nahiz eta haien egoera sozioekonomikoa okerragoa izan. Emaitza horiek gerta daitezke migrazioprozesuan pertsona osasuntsuenen hautaketa bat gertatzen delako, edota osasunarazoak denboraren poderioz azaltzen direlako (Vega et al., 1998). Halaber, babesfaktore soziokulturalen ondorioz gerta daiteke, adibidez, Finch eta Vega-k (2003) demostratu zuten erlijio-sinesmenak edukitzeak babesten zuela osasun mentala. Europa mailan osasun psikologikoaren inguruan egindako zenbait ikerketak adierazi dute etorkinen estres-maila (Amponsah, 2010; Elgorriaga, Ibabe eta Arnoso, 2016; Singhammer eta Bancila, 2011) eta ongizatea (Sam, 1998) bertako populazioarekin alderatuz berdina edo hobeagoa dela.

Alabaina, ikerketa gehiago dira adierazten dutenak etorkinen estres- eta ongizatemaila bertakoena baino okerragoa dela (Baltatescu, 2005; Bartram, 2011; Wittig et al., 2008). Emaitza horiek akulturazioaren estresaren hipotesia defendatzen dute, hau da, akulturazioaren prozesuaren ondorioz osasuna kaltetzen dela (Berry eta Sam, 1996). Zehazki, Europako ikerketa batzuek aditzera eman dute etorkinek estres gehiago (Irfaeya, Maxwell eta Krämer, 2008; Singhammer eta Bancilla, 2011) eta ongizate gutxiago (Baltatescu, 2005) adierazten dutela bertako pertsonekin alderatuta. 
Akulturazio-prozesuaren eta osasun psikologikoaren arteko erlazioa azaltzen duten eredu teoriko nagusiak Lazarus eta Folkman-en (1984) teoria transakzionalean oinarritzen dira, non ulertzen duten estresa edo ondoeza inguruaren ezaugarri eta banakoaren gaitasun eta balorazioaren fruitu dela. Definizio horretan oinarrituz eta beste autore batzuekin bat eginez (Birman, Trickett eta Buchanan, 2005; Prilleltensky, 2008), eredu horiek babesten dute akulturazio-prozesuan sortzen den tentsioa banako, erlazio, komunitate eta testuinguru faktoreen analisietatik ulertu behar dela, jatorrizko herrialdearen eta herrialde hartzailearen egoerak kontuan hartuz (Berry, 1997; Berry et al., 1987; Ward et al., 2001). Horretarako aldagai batzuk zehaztu dituzte, non, ezaugarri soziodemografikoak eta prozesuarenak neurtzen dituzten, eta desberdintzen dituzte migratu aurreko aldagaiak (adibidez, hezkuntza, emigratzeko egitasmoak, gizarte berriko egonaldiarekiko iguripenak eta lan-egoera migratu baino lehen) eta jomuga den gizartean sortzen direnak (adibidez, egonaldiaren iraupena, egoera sozioekonomikoa, akulturazio-estrategiak, hautemandako diskriminazioa, babes-sareak eta kontaktua). Era berean kontaktuko gizarteek (jatorrizkoa vs hartzaileak) dituzten faktore sozial, politiko eta demografikoak neurtzen dituzte, baita euskarri soziala eta komunitatea osatzen duten beste taldeekiko jarrerak ere. Aldagai horien ikerketak etorkinen heterogeneotasun eta proiektu migratzailera gerturatzeko aukera ematen du eta, horrela, testuinguru eta era zehatz batean osasun psikologikoaren ezaugarriak aztertzea ahalbidetzen du (Birman et al., 2005). Uste horiek Prilleltensky-rekin (2008) bat datoz, hau da, etorkinen ongizatea gertakari maila anitzekoa, dinamikoa eta elkarren menpekoa dela. Maila anitzekoa, faktore azaltzaileak maila pertsonalekoak, taldekoak, erakundekoak eta kulturalak izan daitezkeelako; dinamikoa, aldagaiek elkarri eragin diezaioketelako; eta elkarren menpekoa, hartzailearen testuinguruaren ezaugarriek talde kulturalaren ezaugarriei eragiten dietelako, eta horrela, talde bakoitzari baldintza ezberdinak ezarri. Azken alderdi horretan sakonduz, egiaztatu da gizarte hartzaileak baldintzatzen duela etorkinak oinarrizko errekurtsoetara duen sarbidea, akulturazio-prozesua erraztuz edo zailduz kategoria sozial batzuen arabera, hala nola jatorri kulturalaren arabera (Ward eta Kagitcibasi, 2010) edo generoaren arabera (Gregorio, 1997).

\section{Akulturazio-prozesuak, jatorri kulturala eta distantzia kulturala}

Gizarte berri batera ailegatzean, beste gauza batzuen artean, azaleratzen dira bertako kulturak eta jatorrizko kulturak dituzten desberdintasunak. Gizarte bakoitzak ditu ezaugarri batzuk pertsonek ikasten dituztenak sozializazio-prozesuan eta erakusten dituztenak gizarte bakoitzean zer den baliagarria edota onartzen dena, eta zer gauza dauden gaizki ikusiak edo ez diren onartzen. Ezaugarri horiek, hau da, gizarte batek erabiltzen dituen hitzek, keinuek, ohiturek, arauek, hizkuntzek edota sinesmen multzoek kultura zehatz bat osatzen dute (Oberg, 1954). Pertsona bat beste gizarte batera ailegatzen denean kultura desberdin batean kokatzen da, non ezagunak ziren eredu kulturalek zentzua galtzen duten, eta beste berri batzuk ulertu edota ezagutu behar ditu (Moro eta Lachan, 2004; Páez eta Zlobina, 2007). Hautematen diren desberdintasunek esplikatzen dute gertatzen den talka kulturala. Kontzeptu hori erabiltzen da identifikatzeko kultura berri batean bizitzeagatik pertsona batek sufritu dezakeen desorientazioa, frustrazioa edota depresioa (Smith eta Bond, 1993). 
Testuinguru ezberdinetan egindako ikerketek zera frogatu dute: gizarte hartzailearekin zenbat eta distantzia kultural handiagoa duten pertsonek (erreala edota hautemana) orduan eta zailtasun sozioekonomiko, psikosozial eta kultural handiagoei aurka egin behar dietela (adibidez, Berry, 1997; Nesdale eta Mak, 2003; Ward eta Kennedy, 1999; Ward, Bochner eta Furman, 2001); izan ere, esfortzu handiagoa egin behar dute ulertzeko eta ikasteko hizkuntza, ohiturak, komunikaziorako behar diren trebetasun sozialak, arauak, rolak, sinesmenak, balioak eta abar; eta gainera, gutxiespen-egoera gehiago pairatzen dituzte lanarloan, etxebizitza bilatzean edota giza harremanetan. Zailtasun kopuru handiago horrek azaltzen du estres-maila altuagoa eta ongizate gutxiago izatea testuinguru hartzailearekiko distantzia kultural handiagoa dutenean edo hautematen dutenean (Smith eta Bond, 1993; Ward et al., 2001).

Euskal Herriaren kasuan, pertsona saharauiarrak eta Ipar Afrikakoak dira distantzia kultural handiena hautematen dutenak; Latinoamerikarren kasuan, berriz, distantzia maila ertainekoa da, eta Ekialdeko europarrak dira gertukoen sentitzen direnak (Basabe, Zlobina eta Páez, 2004). Halaber, biztanleria magrebtarrak eta saharauiarrak dira egoera sozial prekarioena bizi dutenak beren diru-sarrerak, hezkuntza, estatus sozial eta estatus legala kontuan harturik (Martínez-Taboada, Arnoso eta Elgorriaga, 2006; Sevillano et al., 2013). Era berean, beste komunitateetan gertatzen den moduan (Díez Nicolas, 2010; Navas eta Cuadrado, 2003), Euskal Herrian magrebtarrak eta saharauiarrak dira Europarekin, garatutako herrialdeekin, Asiarekin edo Latinoamerikarekin alderatuz okerren baloratzen diren taldeak herrialde hartzaileko biztanleriaren aldetik (Arnoso, Martínez-Taboada, Elgorriaga eta Otero, 2009).

\section{Akulturazio-prozesuak eta genero-ezberdintasunak}

Gizarte hartzailean egiten diren desberdintasunak etorkinekiko haien jatorriaren arabera ez dira murrizten bakarrik kulturaren arlora. Sortzen diren erlazio asimetrikoak eta baldintzatzaileak beste kategoria sozialetara zabaltzen dira, hala nola generora (Gregorio, 1997). Generoa sozialki eraikitako kontzeptu bat da, kultura bakoitzak desberdintasun sexualak oinarri hartuta gizonekiko eta emakumeekiko garatzen dituzten ideia, sinesmen, rol eta irudikimen multzoa (Lamas, 1997). Eraikuntza sozial horrek pertsonen bizi soziala antolatzen du, baita botere-erlazioak ezartzeko modu bat eragin ere (Scott, 1990). Horrela, generoak baldintzatzen ditu pertsonekiko dauden igurikimenak, eskaerak, rolak, zailtasunak, aukerak eta abar, bai jatorrizko gizartean baita gizarte hartzailean ere.

Emakumeek bizi dituzten eskasia sozioekonomikoak, ezberdintasunak dirusarreretan, beste pertsonen zaintzaren ardura eta genero-indarkeria dira emakumeek oro har gizonek baino osasun mental okerragoa azaltzearen arrazoi batzuk (WHO, 2010). Akulturazio-prozesuetan ikerketek adierazi dute atzerriko emakumeen kasuan, atzerriko gizonekin alderatuz diskriminazio-egoera gehiago jasaten dituztela (Solé, 2000), arazo sozioekonomiko eta legal gehiago dituztela (Standing, 2000) eta gainkarga eta rol eta balioen arteko gatazkari aurre egin behar diotela (Aroian, Norris eta Chiang, 2003). Hau da, genero arteko desberdintasunak mantentzen dira 
akulturazio-prozesuetan. Egoera horiek denek justifikatzen dute emakume etorkinen osasun psikologikoa gizonenarekin konparatuta okerragoa izatea (Amponsah, 2010; Elgorriaga et al., 2016; Jasinskaja-Lahti, Liebkind eta Perhoniemi, 2006; Patiño eta Kirchner, 2008).

\section{Ikerketaren helburuak eta hipotesiak}

Literatura zientifikoaren errebisioak azpimarratzeko diren ideia interesgarri batzuk azaleratzen ditu. Lehenik eta behin, egiaztatu da prozesu migratzaileak efektu desberdinak dituela etorkinen osasun mentalean eta emigratzeak ez duela beti suposatzen estresa agertzea edo ongizatea gutxitzea. Orobat, ikerketek nabarmendu dute testuinguru kulturalak eta talde migratzailearen ezaugarriek (adibidez, kultura, generoa, hezkuntza, emigratzeko egitasmoak, gizarte berrian egonaldiarekiko iguripenak eta lan-esperientzia) baldintzatzen dituztela akulturazioprozesuko ezaugarriak (adibidez, lan- eta etxebizitza-egoera, harreman sozialak eta diskriminazio-prozesuak), eta, ondorioz, hautemandako estres- eta ongizate-mailak (adibidez, Prilleltensky, 2008; Ward et al., 2001).

Euskal Herria testuingurura bideratuz ikerketa batzuk egin dira aurreiritzi eta diskriminazio-prozesuak ezagutzeko (Arnoso et al., 2009), akulturazio-prozesua deskribatzeko (Basabe et al., 2004; Basabe, Páez, Aierdi, eta Jiménez-Aristizabal, 2009) edo etorkinen ongizatea neurtzeko (Sevillano et al., 2013), baina estresak arreta gutxiago jaso du. Interesgarria izango litzateke estres-maila eta ezaugarriak neurtzea eta ongizatearen azterketan sakontzea, ezagutzeko Euskal Herrian bizi diren etorkinen ongizatea eta estresa zer aldagaik aurresaten duten. Akulturazioprozesuak aztertzen direnean beharrezkoa da ikerketa espezifikoak egitea testuinguru bakoitzean, talde bakoitzarekin ezaugarriak aldatzen direlako eta informazio espezifikoa behar delako modu egokian ulertzeko testuinguru bakoitzeko errealitatea (Berry, 1997; Birman et al., 2005). Modu horretan, baliagarriak eta espezifikoak diren elementuak ezagutzen dira populazio zehatz batekin lan egiteko, bai prebentzioko esku-hartzeak garatzeko bai interbentzioko esku-hartzeak egiteko estres-maila altua denean edo ongizatea baxua denean.

Honako ikerketa hau Magrebeko eta Latinoamerikako atzerritarretan zentratzen da, Euskal Herrian duten gehiengo presentziarengatik, bertako kulturarekiko duten distantzia kulturala desberdina delako bai erreala (Hofstede, 1991) bai hautemana (Basabe et al., 2004), eta bertako biztanleriak desberdin baloratzen dituen bi talde direlako (Arnoso et al., 2009; Ikuspegi, 2010). Horrek emango digu aukera neurtzeko distantzia kulturalaren eragina eta eskainiko dizkigu baliabideak erantzunak emateko etorkin kopuru garrantzitsu bati. Helburuak hauek dira:

- Ezagutzea Euskal Herrian bizi diren etorkinen akulturazio-prozesuaren ezaugarriak, kultura eta sexua kontuan hartuta.

- Zehaztea akulturazio-prozesuan zein faktorek aurresan dezaketen magrebtarren eta latinoamerikarren estres- eta ongizate-maila.

- Aztertzea ea biztanleria migratzaileak, euskal biztanleriarekin alderatuz eta sexua kontuan hartuz, estres gehiago eta ongizate gutxiago duen. 
Ikusita prozesu migratzaileak heterogeneoak direla (Birman et al., 2005) eta jatorri kulturalak eta generoak baldintzatzen dituztela akulturazio-prozesuen ezaugarriak (Aroain et al., 2003; Ward eta Kagitcibasi, 2010) eta markatzen dituztela egon daitezkeen zailtasunak (adibidez, hizkuntzarekikoak, lana eta etxebizitza lortzeko, dauden behar sozialak, sare sozial txikiagoak edo diskriminazio handiagoa), espero da Magrebeko etorkinek Latinoamerikako etorkinekin alderatuta zailtasun gehiago edukitzea akulturazio-prozesuan eta, aldi berean, emakumeek gizonek baino zailtasun gehiago edukitzea (Hip. 1). Halaber, espero da akulturazio-prozesuen zailtasunak (adibidez, hizkuntzarekikoak, lana eta etxebizitza lortzeko, dauden behar sozialak, sare sozial txikiagoak edo diskriminazio handiagoa) hautemandako estresaren eta ongizatearen aurresale izatea. Izan ere, akulturazio-prozesuan pertsonek bizi dituzten aldaketek eta zailtasunek estres-maila altua eta ongizatearazoak sor ditzakete (Birman et al., 2005; Prilleltensky, 2008; Ward et al., 2001) (Hip. 2). Estres-akulturazioaren hipotesian oinarrituz (Berry eta Sam, 1996) eta akulturazioprozesuan bizi diren aldaketak eta zailtasunak kontuan hartuz, espero da etorkinek bertako biztanleek baino estres-maila altuagoa eta ongizate-maila okerragoa izatea. Era berean, eta jakinda bi etorkin taldeek distantzia kulturala desberdina dutela eta magrebtarren kasuan handiagoa dela, espero da magrebtarrek latinoamerikarrek baino estres gehiago eta ongizate gutxiago adieraztea (Martínez-Taboada et al., 2006; Sevillano et al., 2013) (Hip. 3). Azkenik, espero da emakumeek gizonek baino estres gehiago eta ongizate gutxiago azaltzea (Jasinskaja-Lahti et al., 2006; Patiño eta Kirchner, 2008) (Hip. 4).

\section{Metodologia}

\subsection{Lagina}

Lagina Euskal Autonomia Erkidegoan bizi diren 405 etorkinek osatzen dute. Horietatik \% 50,9 emakumeak dira $(n=206)$ eta \% 49,1 gizonak $(n=199)$. Gazteak dira $(M=33,71$; urte; $S D=8,82)$ eta 4 urte daramatzate Euskadin $(M=48,13$ hilabete; $S D=39,94)$. Jatorriari dagokionez, \% 50,4 Magrebetik dator $(n=204)$ eta \% 49,6 Latinoamerikako herrialdeetatik $(n=201)$. Bi talde horiek hartu dira, kultur distantzia irizpide hartuta, talde horiek distatzia-maila desberdinak irudikatzen dituztelako bertako kulturarekiko (Hostede, 1991). Gainera, Basabe eta besteek(2004) egiaztatu zuten Magrebeko taldeak, Latinoamerikako taldearekin konparatuta, bertako jendearekiko desberdintasun handiagoa hautematen zuela.

Beste alde batetik, eta konparazioak egiteko, bertako pertsonek osatutako lagin adierazle bat ere egin zen $(n=306)$ INEren irizpideak kontuan hartuta (INE, 2010: batez besteko adina 47,75, \% 51,44 emakumeak eta \% 48,55 gizonak). Horrela, $\%$ 49,7 emakumeak ziren eta \% 50,3 gizonak, eta batez besteko adina 44,76 urtekoa.

\subsection{Datu-bilketako tresnak eta galde-sortak}

Akulturazio-prozesua deskribatzeko: ad hoc galdetegi bat egin zen Berry-k (1997) eta Ward eta besteek (2001) proposatutako ereduetan oinarrituz. Ezaugarri hauek ezagututa jakin ditzakegu prozesu honetan etorkinek bizi dituzten zailtasunak: 
a) Aldagai soziodemografikoak: sexua, jatorrizko nazionalitatea, adina, familia-egitura (bikotea, seme-alabak eta beste familiarrak), prestakuntza eta gaztelania-maila.

b) Migratu aurreko egoera: emigratzeko egitasmoa, gizarte berriko egonaldiarekiko iguripenak eta lan-egoera migratu baino lehen.

c) Jomuga den gizartean duten egoera: zenbat denbora herrialde berrian, lan-egoera, egoera legala, etxebizitza, aurre-egite psikosoziala (harrera, egokitzapen psikosoziala edo autonomia soziala), beharrak (dokumentazioa, laguntza sozialak, lana eta etxebizitza).

Hautemandako distantzia kulturala: Bergamik eta Bagozzik (2000) diseinatutako eskala grafiko bat erabili zen. 2 borobil desberdinekin jatorrizko kultura edo gizartea, eta kultura edo gizarte berria irudikatzen dira, bata bestearen parean jarrita. Horrela, eskala horrek 8 marrazki edo aukera ematen ditu (bi borobil guztiz solapatutik, bi borobil guztiz separatura). Gainera, marrazki bakoitza idatzizko aukera batekin lotzen da ( 1 = guztiz hurbil; 8 = guztiz urrun). Modu horretan distantzia kulturala edo talde zehatz batekiko identifikazio-maila neurtzen da.

Hautemandako diskriminazioa: beste ikerketa batzuetan bezala (Basabe et al., 2009; Jasinskaja-Lahti et al., 2006), Likert motako lau item sortu dira (1 = ezer ez; 5 = asko). Adibidez, (Zer diskriminazio-maila hautematen duzu zure lantokian?). Fidagarritasuna ona izan zen, alpha ,75.

Harreman eta babes sareak: Likert motako sei item sortu dira, Basabek, Paezek eta Zlobinnak (2004) egindako lanean oinarrituz, 3 item harremanak neurtzeko ( 1 = oso gutxi; 5 = asko) eta beste 3 item babesa neurtzeko ( 1 = baxua; $5=$ altua). Bi kasuetan hiru talde desberdin kontuan hartzen dira (endotaldea, beste etorkinen taldeak eta bertakoak). Adibidez, (Zer harreman-maila duzu bertako pertsonekin? Galdera bakoitza indibidualki analizatzen da.

Estresa: Perceived Stress Scale (PSS-14; Cohen, Kamarak eta Mermelstein, 1983; gaztelaniazko bertsioa Remor eta Carrobles, 2001). Eskala honek neurtzen du zer puntutaraino pertsona batek bizi dituen gertaerak aurresanezinak, kontrolaezinak diren edota gainkarga eragiten duten. Likert moduko 14 item ditu $(0=$ inoiz ez; 4 = sarritan) eta egokia da etorkinen laginekin erabiltzeko (Navara eta James, 2002; Patiño eta Kirchner, 2008). Fidagarritasuna ona izan zen, alpha ,82.

Ongizatea: Satisfaction With Life Scale (SWLS; Diener et al., 1985; gaztelaniazko bertsioa Atienza et al., 2000). Likert moduko 5 itemek osatzen dute eskala hau ( $1=$ guztiz desados; 5 = guztiz ados) eta bizi-ongizatea edota iguripen eta lorpenen arteko balorazioa neurtzen dute. Ikerketa desberdinek ikusarazi dute egokia dela etorkinen laginekin lan egiteko (p.e., Basabe et al., 2009; Neto, 1995). Fidagarritasuna ona izan zen, alpha ,88.

\subsection{Prozedura}

Laginarekin kontaktuan jartzeko bi modu erabili ziren: alde batetik, Gipuzkoako Gurutze Gorrira joan ginen, laguntza eskatzen duten etorkinekin egoteko eta 
ikerketa-taldeko kide batek galderak egin zizkien. Beste alde batetik, autonomoa den jendea aurkitzeko eta bertako jendearekin hitz egiteko elurrezko bolaren teknika erabili zen (Taylor eta Bogdan, 1986). Prozedura horren bidez, ditugun sare sozialak erabili ziren bai etorkinekin bai bertako jendearekin kontaktuan jartzeko. Gutunazal batean sartu genuen galdetegia eta zuzenean edo kontaktu baten bitartez partehartzaileei eman genien. Haiek modu autonomo batean bete eta bueltatzen zuten, bai zuzenean ikertzaile taldeari bai kontaktuaren bitartez.

Galdetegia eta tresnak gaztelaniaz zeuden. Kasu guztietan anonimotasuna eta konfidentzialtasuna gorde ziren. Hori ziurtatzeko galdetegiaren hasieran testu batean aipatzen zen. Galderak presentzialki egiten zirenean, ikertzaileak zuzenean esplikatzen zien ez zela izena hartzen, datu guziak batera aztertzen zirela eta ikertzaileak, nahiz eta jakin pertsonaren erantzunak, ez zuela ezer esango.

Ikerketa transkulturaletan edo atzerriko etorkinekin egiten direnetan prozedurarekin zerikusia duten alborapenak ager daitezke, hori ekiditeko zenbait baliabide martxan jarri ziren (Vergara eta Balluerka, 2000): hau da, beste ikerketa batzuetan etorkinekin erabilitako tresnak aukeratu ziren, galde-sortak egin zituen pertsonak gaitasun kulturaletan entrenamendua jaso zuen eta bitartekarien laguntza izan genuen gaztelania menperatzen ez zuten pertsonei laguntzeko. Gainera, ikerketa piloto bat egin zen etorkin beste talde batekin $(N=103)$ zihurtatzeko ulertzen zituztela egindako galderak eta probatzeko tresnen fidagarritasuna.

\subsection{Datu-analisiak}

Datuen tratamendurako SPSS 20 programa erabili zen. Akulturazio-prozesuen ezaugarriak ezagutzeko eta kultura eta generoaren arabera desberdintasunik dagoen aztertzeko analisi deskribatzaileak egin ziren: alde batetik, ANOVAk erabili ziren aldagai kuantitatiboekin batez bestekoetan desberdintasunik dagoen analizatzeko eta Tukey probak zehazteko zer talderen artean azaltzen ziren aurkitutako desberdintasunak; beste aldetik, aldagai kualitatibo edo kategorikoekin khi karratuaren analisiak egin ziren.

Lau erregresio lineal anitzeko analisiak egin ziren etorkinen estresa eta ongizatea aurresaten dituzten aldagaiak ezagutzeko, bi Mabregeko populazioarekin eta bi Latinoamerikako populazioarekin. Hori egin baino lehen korrelazio-analisiak egin ziren talde bakoitzean identifikatzeko zer aldagai erlazionatzen ziren estresarekin eta ongizatearekin. Kualitatiboak eta kategorikoak ziren aldagaiak dummy aldagaiak bihurtu ziren korrelazioak egin ahal izateko.

Eta azkenik, aztertzeko ea biztanleriak migratzaileak bertako biztanleekin alderatuz eta sexua kontuan hartuz estres gehiago eta ongizate gutxiago zuen, bi ANOVA analisi egin ziren ( $2 \times 3$ eredua) parte-hartzaileen sexua (gizona vs emakumea) x jatorri kulturala (Magreb vs Latinoamerika vs Euskal Herria) eginda; menpeko aldagaiak estresa eta ongizatea izan ziren. 


\section{Emaitzak}

\subsection{Akulturazio-prozesuaren ezaugarriak}

Euskadin bizi diren etorkinen akulturazio-prozesuen ezaugarriak ezagutzeko zenbait aldagai neurtu dira: soziodemografikoak, migratu aurreko egoerakoak eta jomuga den gizartearen egoerakoak.

\section{Aldagai soziodemografikoak}

Lehenengo taulan ikus daitekeen bezala, aldagai soziodemografikoak aztertzean desberdintasun esanguratsuak aurkintzen dira etorkinen jatorria eta sexua kontuan hartzean. Latinoamerikako emakumeak besteekin konparatuta zaharragoak dira. Nahiz eta erdiek bikotekidea eduki, Latinomerikako gizon gehiagok bikotea dute. Hala ere, kasu guzietan ezin dira elkarrekin egon, eta egoera hori handiagoa da Magrebeko gizonen artean. Besterik, Latinoamerikako populazioan, bereziki emakumeek, Magrebeko populazioarekin konparatuta pertsona gehiagok ditu seme-alabak. Azkenik, beste familiarren inguruan galdetutakoan ikus daiteke Magrebeko gizonek beste taldeekin konparatuta gutxiagotan dituztela senideak gertu.

\section{1. taula. Ezaugarri soziodemografikoetan dauden} desberdintasun esanguratsuak.

\begin{tabular}{|c|c|c|c|c|c|}
\hline & $\begin{array}{l}\text { Giz. } \\
\text { Magreb }\end{array}$ & $\begin{array}{l}\text { Emak. } \\
\text { Magreb }\end{array}$ & $\begin{array}{l}\text { Giz. } \\
\text { Latinoam. }\end{array}$ & $\begin{array}{l}\text { Emak. } \\
\text { Latinoam. }\end{array}$ & $p$ \\
\hline Adina & $\begin{array}{l}32,11^{d} \\
(7,72)\end{array}$ & $\begin{array}{l}32,71^{d} \\
(8,74)\end{array}$ & $\begin{array}{l}32,01^{d} \\
(9,03)\end{array}$ & $\begin{array}{l}37,03^{a b c} \\
(9,01)\end{array}$ & ,000 \\
\hline $\begin{array}{l}\text { Familia-egitura } \\
\text { Bikotea dauka } \\
\quad \text { Elkarrekin daude } \\
\text { Seme-alabak ditu } \\
\quad \text { Elkarrekin daude } \\
\text { Familiarrak }\end{array}$ & $\begin{array}{l}\% 45,2 \\
\% 48,2 \\
\% 24,2 \\
\% 50 \\
\% 36,3\end{array}$ & $\begin{array}{l}\% 37,5 \\
\% 80 \\
\% 41,3 \\
\% 78,8 \\
\% 61,3\end{array}$ & $\begin{array}{l}\% 68 \\
\% 86,3 \\
\% 64 \\
\% 60,4 \\
\% 70,7\end{array}$ & $\begin{array}{l}\% 49,2 \\
\% 83,9 \\
\% 76 \\
\% 66,7 \\
\% 54\end{array}$ & $\begin{array}{l}, 001 \\
, 000 \\
, 000 \\
\text { e.e.* } \\
, 000\end{array}$ \\
\hline $\begin{array}{l}\text { Prestakuntza } \\
\text { Ez dauka/Badaki } \\
\text { irakurtzen-idazten } \\
\text { Lehen eta bigarren } \\
\text { mailakoak } \\
\text { Goi-mailakoak }\end{array}$ & $\begin{array}{l}\% 15,3 \\
\% 68,5 \\
\% 16,2\end{array}$ & $\begin{array}{l}\% 15 \\
\% 62,5 \\
\% 22,5\end{array}$ & $\begin{array}{l}\% 2,7 \\
\% 65,3 \\
\% 32\end{array}$ & $\begin{array}{l}-- \\
\% 63,5 \\
\% 36,5\end{array}$ & $\begin{array}{l}, 000 \\
\text { e.e.* } \\
, 002\end{array}$ \\
\hline $\begin{array}{l}\text { Gaztelania-maila } \\
\text { Baxua } \\
\text { Ertaina } \\
\text { Altua }\end{array}$ & $\begin{array}{l}\% 16,3 \\
\% 52,8 \\
\% 30,9\end{array}$ & $\begin{array}{l}\% 38,7 \\
\% 37,3 \\
\% 24\end{array}$ & $\begin{array}{l}\% 1,4 \\
\% 4,3 \\
\% 94,2\end{array}$ & $\begin{array}{l}-- \\
\% 3,4 \\
\% 96,6\end{array}$ & ,000 \\
\hline \multicolumn{6}{|c|}{$\begin{array}{l}\text { * e.e.: ez esanguratsua. } \\
\text { abcd: irudikatzen dute zer talderen artean dauden desberdintasunak ( } a=\text { Gizon } \\
\text { magrebtarrak, b = Emakume magrebtarrak, } c=\text { Gizon latinoamerikarrak, } d=\text { Emakume } \\
\text { latinoamerikarrak). } \\
\text { Desberdintasunak ezaqutzeko Tukey post-hoc konparaketak eqin dira. }\end{array}$} \\
\hline
\end{tabular}


Lehen eta bigarren mailako formakuntza duten pertsonen kopurua berdintsua da lau taldeetan, baina badira Latinoamerikako emakume eta gizon gehiago goi-mailako ikasketak dituztenak eta Magrebeko emakume eta gizon gehiago formakuntzarik gabe edo irakurtzen eta idazten dakitenak. Gaztelania-maila (etorkinek hautematen dutena) Magrebeko pertsonek baxuagoa adierazten dute.

\section{Migratu aurreko egoera}

Oro har, jatorrizko herrialdean gehienek okupazio bat zuten, bai lanpostu bat zutelako bai ikasten zeudelako, \% 8,3 bakarrik zegoen langabezian eta $\% 3,5$ ek esklusiboki etxeko lanak egiten zituen. Hala ere, emigratzeko egitasmo garrantzitsuena ekonomikoa da, familiarekin berriro biltzea bigarrena, eta, azkenik, formakuntza, beste arrazoi batzuk eta babes politikoa bilatzea. Erdientzat migrazioproiektua denbora baterako da eta jatorrizko herrialdera bueltatu nahi dute, heren bat betiko etorri da Euskal Herrira, eta \% 20k ez daki geldituko den edo ez.

\section{2. taula. Migratu aurreko ezaugarrietan dauden desberdintasun esanguratsuak.}

\begin{tabular}{|c|c|c|c|c|c|}
\hline & $\begin{array}{l}\text { Giz. } \\
\text { Magreb }\end{array}$ & $\begin{array}{l}\text { Emak. } \\
\text { Magreb }\end{array}$ & $\begin{array}{l}\text { Giz. } \\
\text { Latinoam. }\end{array}$ & $\begin{array}{l}\text { Emak. } \\
\text { Latinoam. }\end{array}$ & $p$ \\
\hline $\begin{array}{l}\text { Lan-egoera } \\
\text { Lana } \\
\text { Etxeko lanak } \\
\text { Ikasi } \\
\text { Langabezia }\end{array}$ & $\begin{array}{l}\% 63,7 \\
-- \\
\% 23,4 \\
\% 12,9\end{array}$ & $\begin{array}{l}\% 51,7 \\
\% 8,8 \\
\% 20 \\
\% 19,5\end{array}$ & $\begin{array}{l}\% 78,7 \\
-- \\
\% 21,3 \\
--\end{array}$ & $\begin{array}{l}\% 85,8 \\
\% 6,3 \\
\% 6,3 \\
\% 1,6\end{array}$ & $\begin{array}{l}, 000 \\
, 004 \\
, 002 \\
, 000\end{array}$ \\
\hline $\begin{array}{l}\text { Emigratzeko egitasmoa } \\
\text { Ekonomikoa } \\
\text { Asilo politikoa } \\
\text { Formakuntza } \\
\text { Familiarekin elkartu } \\
\text { Beste batzuk }\end{array}$ & $\begin{array}{l}\% 79,8 \\
\% 2,5 \\
\% 8,9 \\
\% 4 \\
\% 4,8\end{array}$ & $\begin{array}{l}\% 46,3 \\
\% 5 \\
\% 5 \\
\% 27,5 \\
\% 16,2\end{array}$ & $\begin{array}{l}\% 65,4 \\
\% 1,3 \\
\% 17,3 \\
\% 12 \\
\% 4\end{array}$ & $\begin{array}{l}\% 71,7 \\
\% 2,4 \\
\% 9,4 \\
\% 7,1 \\
\% 9,4\end{array}$ & $\begin{array}{l}, 000 \\
\text { e.e.* } \\
\text { e.e.* } \\
, 000 \\
, 014\end{array}$ \\
\hline $\begin{array}{l}\text { Egonaldiarekiko } \\
\text { iguripenak } \\
\text { Behin betikoa } \\
\text { Behin-behinekoa } \\
\text { Ez daki }\end{array}$ & $\begin{array}{l}\% 44,4 \\
\% 34,7 \\
\% 21\end{array}$ & $\begin{array}{l}\% 29,2 \\
\% 50 \\
\% 20,8\end{array}$ & $\begin{array}{l}\% 16 \\
\% 57,3 \\
\% 26,7\end{array}$ & $\begin{array}{ll}\% & 23,6 \\
\% & 62,2 \\
\% & 14,2\end{array}$ & $\begin{array}{l}, 000 \\
, 000 \\
\text { e.e. }\end{array}$ \\
\hline
\end{tabular}

Lau taldeen artean desberdintasunak ikus daitezke (2. taula). Lan-egoeraren inguruan, Magrebeko emakume gutxiagok zeukaten lanbide bat eta Latinoamerikako emakume gutxiagok ikasten zuten. Langabezia-tasak handiagoak dira Magrebeko populazioan eta etxeko lanak egitea esklusiboki bakarrik emakumeen artean ikusten da. Emigratzeko egitasmoari dagokionez, lau taldeen artean ez dago desberdintasunik formakuntza edo babes politikoaren arrazoiak aztertzean. Hala ere, Magrebeko emakumeek beste taldeekin konparatuta gutxiagotan emigratzen dute arrazoi ekonomikoengatik eta kasu gehiagotan beren herritik ateratzen dira 
familiarekin biltzeko edo beste arrazoi batzuengatik. Azkenik, Magrebeko gizonek besteekin alderatuz kasu gehiagotan ikusten dute beren migrazio-proiektua behin betiko bezala eta gutxiagotan behin-behineko bezala.

Jomugan den gizartearen egoera

Elkarrizketatu diren pertsonek batez beste 4 urte daramatzate Euskal Autonomia Erkidegoan ( $M=48,13$ hilabete, $D T=39,94)$. Ailegatu direnetatik \% 54,8k lana behar edo hobetu nahi zuen, \% 32,5ek laguntza soziala eskatzen zuen eta \% 23,3k dokumentazioa lortzeko laguntza behar zuen.

3. taula. Jomugan den gizartearen egoeran dauden desberdintasun esanguratsuak.

\begin{tabular}{|c|c|c|c|c|c|}
\hline & $\begin{array}{l}\text { Giz. } \\
\text { Magreb }\end{array}$ & $\begin{array}{l}\text { Emak. } \\
\text { Magreb }\end{array}$ & $\begin{array}{l}\text { Giz. } \\
\text { Latinoam. }\end{array}$ & $\begin{array}{l}\text { Emak. } \\
\text { Latinoam. }\end{array}$ & $p$ \\
\hline Lana daukate & $\% 60,5$ & $\% 85$ & $\% 81,3$ & $\% 88,9$ & ,000 \\
\hline Egoera legal egokia & $\% 80,6$ & $\% 90$ & $\% 86,7$ & $\% 92,1$ & ,046 \\
\hline Etxebizitza egokia & $\% 74,2$ & $\% 78,8$ & $\% 90,7$ & $\% 96$ & ,000 \\
\hline $\begin{array}{l}\text { Autonomia } \\
\text { Harrera } \\
\text { Egokitzapen psikosoziala } \\
\text { Autonomia soziala }\end{array}$ & $\begin{array}{l}\% 50 \\
\% 36 \\
\% 14\end{array}$ & $\begin{array}{l}\% 26,1 \\
\% 47,8 \\
\% 26,1\end{array}$ & $\begin{array}{l}\% 26,8 \\
\% 60,7 \\
\% 12,5\end{array}$ & $\begin{array}{l}\% 7,5 \\
\% 80,4 \\
\% 12,1\end{array}$ & ,000 \\
\hline $\begin{array}{l}\text { Beharrak } \\
\text { Etxebizitza }\end{array}$ & $\% 50,8$ & $\% 58,4$ & $\% 37,3$ & $\% 26,2$ & ,000 \\
\hline $\begin{array}{l}\text { Hautemandako distantzia } \\
\text { kulturala }(1-8)\end{array}$ & $4,12^{\mathrm{bcd}}$ & $5,39^{a}$ & $5,23^{a}$ & $4,80^{a}$ & ,000 \\
\hline $\begin{array}{l}\text { Hautemandako } \\
\text { diskriminazio-maila (1-5) }\end{array}$ & $2,06^{b}$ & $2,75^{\text {acd }}$ & $1,70^{b}$ & $1,94^{b}$ & ,000 \\
\hline $\begin{array}{l}\text { Harreman-maila (1-5) } \\
\text { Jatorri berdineko pertsonak } \\
\text { Etorkinak } \\
\text { Babes-maila (1-5) } \\
\text { Etorkinak } \\
\text { Bertako pertsonak }\end{array}$ & $\begin{array}{l}2,96 \\
2,61^{\text {cd }} \\
2,16^{b d} \\
2,65^{\text {bd }}\end{array}$ & $\begin{array}{l}2,75^{\mathrm{c}} \\
2,93 \\
2,58^{\mathrm{a}} \\
3,46^{\mathrm{a}}\end{array}$ & $\begin{array}{l}3,28^{b} \\
3,11^{a} \\
2,48 \\
3,09\end{array}$ & $\begin{array}{l}2,89 \\
3,01^{a} \\
2,54^{a} \\
3,18^{a}\end{array}$ & $\begin{array}{l}, 040 \\
, 009 \\
, 014 \\
, 000\end{array}$ \\
\hline \multicolumn{6}{|c|}{$\begin{array}{l}\text { abcd: irudikatzen dute zer talderen artean dauden desberdintasunak ( } \mathrm{a}=\text { Gizon } \\
\text { magrebtarrak, } b=\text { Emakume magrebtarrak, } c=\text { Gizon latinoamerikarrak, } d=\text { Emakume } \\
\text { latinoamerikarrak) } \\
\text { Desberdintasunak ezagutzeko Tukey post-hoc konparaketak egin dira. }\end{array}$} \\
\hline
\end{tabular}

Bertako gizartearekiko duten identifikazio-maila ertaina da $(M=4,79 ; D T=1,91)$ eta hautemandako diskriminazioa baxua $(M=2,09 ; D T=1,19)$. Bertako pertsonekin duten harreman-maila «ertaina-altua» da $(M=3,45 ; D T=1,05)$. Beste aldetik, jatorri berdina duten pertsonengandik jasotzen duten babesa $(M=2,62 ; D T=1,16)$.

Hala ere, lau taldeen arteko desberdintasun esanguratsuak ikus daitezke (3. taula). Oro har, Magrebeko gizon gehiago daude harrera-prozesuetan (laguntza 
behar dute migrazioari aurre egiteko). Gizon horiek arazo gehiago dituzte lana lortzeko eta beren egoera legala erregulatzeko, eta Magrebeko emakumeekin batera, etxebizitza-arazo gehiago dituzte.

Bertako gizartearekiko hautematen duten distantzia kulturala handiagoa da gizon magrebtarren artean eta Magrebeko emakumeetan hautemandako diskriminazioa handiago da.

Jatorri berdina dutenekin harreman-maila altuagoa da Latinoamerikako gizonetan Magrebeko emakumeetan baino, eta beste etorkinekin harreman-maila Latinoamerikako populazioan altuagoa da Magrebeko gizonetan baino. Emakumeak, bai magrebtarrak bai latinoamerikarrak, Magrebeko gizonekin konparatuta babesmaila altuagoa jasotzen dute bertako pertsonengandik eta beste etorkinengandik.

\subsection{Magreb eta Latinoamerikako etorkinen estresa eta ongizatea aurreikusteko ereduak}

Populazio bakoitzean estresa eta ongizatea aurreikusten dituzten aldagaiak ezagutzeko lau erregresio lineal anitzeko analisiak egin ziren (4. taula). Ongizatea analizatzean Magrebeko taldean, bost aldagai esanguratsu agertu ziren $\left(R^{2}=, 20\right.$, $F(4,202)=10,91 ; p<, 001)$ : lan-egoera, familiarrak hurbil edukitzea, harremanak jatorri berdineko pertsonekin, etxebizitza-beharrak edukitzea eta hautemandako distantzia kulturala. Latinoamerikako taldean, berriz, zazpi faktorek esplikatzen zuten ongizatea $\left(R^{2}=, 40, F(6,199)=11,90 ; p<, 001\right)$ : harremanak jatorri berdineko pertsonekin, laguntza sozialak edukitzea, babesa bertako pertsonengandik, prestakuntza, sexua, adina eta lan-beharrak edukitzea.

Beste aldetik, estresa aurresateko hiru faktore esanguratsuak izan ziren Magrebeko taldean $\left(R^{2}=, 11, F(2,202)=8,08 ; p p<, 001\right)$ : laguntza sozialak, babesa bertako pertsonengandik eta hautemandako diskriminazioa. Latinoamerikako taldearekin, berriz, sei aldagaik aurreikusten zuten estresa $\left(R^{2}=19, F(4,199)=8,29\right.$; $p<, 001)$ : familiarrak hurbil edukitzea, etxebizitza-beharrak edukitzea, laguntza sozialak edukitzea, babesa bertako pertsonengandik, hautemandako diskriminazioa eta autonomia. 


\section{4. taula. Estresa eta ongizatea aurreikusten dituzten aldagaiak Magreb eta Latinoamerikako populazioetan.}

\begin{tabular}{|c|c|c|c|c|}
\hline & \multicolumn{2}{|c|}{ Ongizatea } & \multicolumn{2}{|c|}{ Estresa } \\
\hline & $\begin{array}{l}\text { Magreb } \\
\text { (Beta } \\
\text { koefizienteak) }\end{array}$ & $\begin{array}{l}\text { Latinom. } \\
\text { (Beta } \\
\text { koefizienteak) }\end{array}$ & $\begin{array}{l}\text { Magreb } \\
\text { (Beta } \\
\text { koefizienteak) }\end{array}$ & $\begin{array}{l}\text { Latinom. } \\
\text { (Beta } \\
\text { koefizienteak) }\end{array}$ \\
\hline Lan-egoera & $17^{*}$ & -- & -- & -- \\
\hline $\begin{array}{l}\text { Familiarrak hurbil } \\
\text { edukitzea }\end{array}$ &, $18^{* *}$ & & &,$- 19^{*}$ \\
\hline $\begin{array}{l}\text { Harremana (jatorri } \\
\text { berdineko pertsonak) }\end{array}$ &, $16^{*}$ & ,20** & -- & -- \\
\hline $\begin{array}{l}\text { Hautemandako } \\
\text { distantzia kulturala }\end{array}$ &, $15^{*}$ & -- & -- & -- \\
\hline Etxebizitza-beharrak &,$- 16^{\star}$ & -- & &, $23^{\star \star}$ \\
\hline Laguntza sozialak & -- &,$- 35^{\star \star \star}$ & $15^{\star}$ & $36^{\star * *}$ \\
\hline $\begin{array}{l}\text { Babesa (bertako } \\
\text { pertsonak) }\end{array}$ & -- &, $30^{* \star *}$ &,$- 24^{\star \star}$ &,$- 21^{\star *}$ \\
\hline Prestakuntza & -- &, $23^{\star \star}$ & -- & -- \\
\hline Sexua: gizona & -- & $26^{\star \star}$ & -- & -- \\
\hline Adina & -- &, $19^{\star \star}$ & -- & -- \\
\hline Lan-beharrak & -- &,$- 16^{*}$ & -- & -- \\
\hline $\begin{array}{l}\text { Hautemandako } \\
\text { diskriminazioa }\end{array}$ & -- & -- &, $16^{*}$ &, $21^{\star \star}$ \\
\hline Autonomia & -- & -- & -- &,$- 24^{\star *}$ \\
\hline $\begin{array}{l}F \text { Eredua } \\
R^{2}\end{array}$ & $\begin{array}{l}10,91^{* * *} \\
, 20\end{array}$ & $\begin{array}{l}11,90^{* * *} \\
, 40\end{array}$ & $\begin{array}{l}8,08^{\star * *} \\
, 11\end{array}$ & $\begin{array}{l}8,29^{* \star *} \\
, 19\end{array}$ \\
\hline
\end{tabular}

${ }^{*} \mathrm{p} \leq .05 .{ }^{* *} \mathrm{p} \leq .01$. ${ }^{\star * *} \mathrm{p} \leq .001$.

\subsection{Etorkinen ongizatea eta estres-maila bertako biztanleriarekin konparatuta}

Bi ANOVA analisi egin ziren $(2 \times 3$ eredua) parte-hartzaileen sexua (gizona vs emakumea) x jatorri kulturala (Magreb vs Latinoamerika vs Euskal Herria) eginda; menpeko aldagaiak estresa eta ongizatea izan ziren. Estresa adieraztean, efektu nagusi bakarra aurkitu zen: jatorri kulturala hain zuzen $(F(1,709)=7,58$; $p=, 001$; $\left.\eta^{2}=, 021\right)$. Magrebeko pertsonek $(M=1,74 ; D T=, 62)$ Latinoamerikako pertsonek $(M=1,57 ; D T=, 64)(p=, 001)$ eta bertako pertsonek $(M=1,54 ; D T=, 51)(p=, 009)$ baino estres altuagoa hautematen zuten.

Ongizatea analizatzean, jatorri kulturalaren efektua $(F(2,701=58,74 ; p p<, 001$; $\left.\eta^{2}=, 014\right)$ eta interakzio-efektua esanguratsuak izan ziren $(F(2,701)=3,15 ; p=, 043$; $\left.\eta^{2}=, 009\right)$. Alde batetik, Latinoamerikako $(t=-, 749 ; p=, 455)$ eta Euskal Herriko populazioan $(t=-, 297 ; p=, 767)$ ez dago desberdintasun esanguratsurik gizonen eta emakumeen artean ongizate-mailan. Magrebeko taldean, berriz, emakumeek 
gizonek baino ongizate gehiago adierazten dute $(t=2,37 ; p=, 018)$. Beste aldetik, Magrebeko emakumeek $(M=3,03)$ Latinoamerikako eta bertako emakumeekin konparatuta ongizate gutxiago adierazten dute $(M=3,48$ eta $M=3,67)$ $(F(2,253)=17,20 ; p<, 001)$. Gizonen egoera aztertzean fenomeno berdina aurkitzen da, Magrebeko gizonek $(M=2,72)$ Latinoamerikako eta bertako gizonek baino ongizate gutxiago adierazte dute $(M=3,58$ eta $M=3,77)(F(2,348)=47,48 ; p<, 001)$.

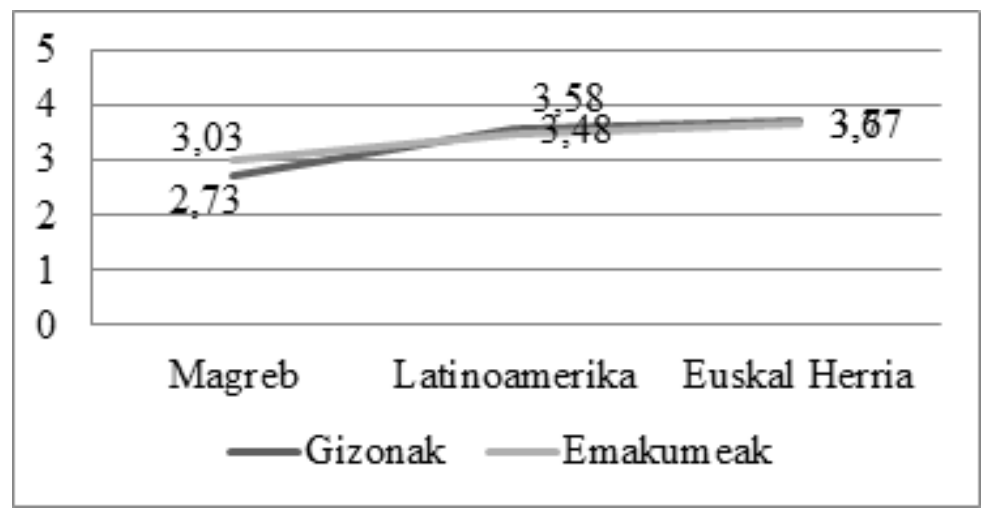

1. Irudia. Ongizate-maila jatorri kultural eta sexuaren arabera.

\section{Diskusioa eta ondorioak}

Beste herrialde batera migratzeak eta testuinguru horretara egokitzeak ondorioak izan ditzake etorkinen osasun psikologikoan, baina horrek ez du esan nahi egoera psikologikoa beti negatiboa denik. Egokitzapen-prozesuak askotarikoak dira eta maila desberdinetako aldagaiek (indibidualak, errelazionalak, erakundekoak eta testuingurukoak) esplikatzen dituzte prozesu horien emaitzak, horien artean, pertsonek adierazten dituzten ondorio psikologikoak ezberdinak izatea (Berry, 1997; Prilleltensky, 2008): batzuek arazoak sufritzen dituzte, beste batzuek ez dute aldaketarik nabaritzen, eta beste batzuek beren osasuna hobetzen dute. Prozesuetan eta emaitzetan dauden desberdintasunak direla-eta egile batzuek gomendatzen dute testuinguru bakoitzean eta talde kultural bakoitzarekin ikerketa espezifikoak egitea (Berry, 2003). Horrela, azterlan hau burutu zen Euskal Herrian bizi diren etorkinen akulturazio-prozesuaren ezaugarriak ezagutzeko eta haien osasun psikologikoaren (estresa eta ongizatea) ezaugarriak definitzeko. Horretarako, Euskal Herrian presentzia gehien duten bi taldeak, latinoamerikarrak eta magrebtarrak, hartu ziren kontuan.

\section{Akulturazio-prozesuaren ezaugarriak kultura eta sexua kontuan hartuta}

Lehenengo helburua planteatu zen Euskal Herrian bizi diren magrebtarren eta latinoamerikarren akulturazio-prozesuaren ezaugarriak ezagutzeko, kultura eta sexua kontuan hartuta. Emaitzek adierazten dute Latinoamerikako populazioaren egoerak, bai emakumeenak bai gizonenak, berdintsuak direla eta oztopo gutxiago dituztela Magrebeko populazioarekin konparatuta. Hain zuzen ere, haien prestakuntza eta 
gaztelania-maila altuagoa da, lan-esperientzia gehiago dute eta zailtasun gutxiago etxebizitza eta lan-egoera hobetzeko. Emaitza hauek bat datoz Zlobinna eta besteek (2006) aurkitu zituztenekin testuinguru eta populazio berdinean. Beste alde batetik, Magrebeko gizonek emakumeekin alderatuta eta Latinoamerikako populazioarekin alteratuta oztopo gehien duen azpitaldea da (prekarietate handiagoa du lanean, arlo legalean eta etxebizitza lortzeko arazo gehiago ditu eta haien sare sozialak txikiagoak dira). Bestetik, Magrebeko emakumeek gehiagotan emigratu dute familiarekin elkartzeko edo arrazoi desberdinengatik (ekonomikoak, politikoak eta formakuntza izan ezik), beste lan batzuetan ikusi den bezala (Gregorio eta Ramirez, 2000). Baieztatzen da diskriminazio gehien hautematen duen taldea dela (Solé, 2000), baina bertako gizartearekin gehien idenfikatzen direnak dira, seguruenik orekatzeko konparazio baten emaitza kaltegarria (Tajfel eta Turner, 1979; Montero, 1996). Latinoamerikako populazioa aztertzean ikusten da gizonen eta emakumeen baldintzak parekoak eta positiboagoak direla. Gehienek oinarrizko beharrak asetuak dituzte, babesa jasotzen dute eta kontaktua dute talde desberdinekin, ez dute diskriminaziorik hautematen eta bertako gizartearekin identifikatzen dira, batez ere emakumeak.

Nahiz eta ikusi pertsona batzuek zailtasun sozioekonomikoak dituztela Euskal Herrira etortzeko, orokorrean esan dezakegu Latinoamerikako eta Magrebeko pertsonek gaitasunak eta errekurtsoak dituztela sortzen diren arazoei erantzun bat emateko eta egokitzapenari aurre egiteko.

Emaitza hauek planteatutako lehenengo hipotesia partzialki baieztatzen dute: a) kulturaren arabera ikusi da Magrebeko populazioak Latinoamerikako populazioak baino zaitasun gehigo dituela; b) baina ezin da baieztatu emakumeek zailtasun gehigo dituztenik, ikusi delako Magrebeko gizonek emakumeek baino zailtasun gehiago dituztela eta Latinoamerikako taldean ez dagoelako desberdintasunik gizonen eta emakumeen artean. Horrela, lan honek bat egiten du zenbait ikerketarekin, non egiaztatzen duten zenbat eta distantzia handiagoa, orduan eta zailtasun gehiago egongon direla akulturazio-prozesuan (Smith eta Bond, 1993; Ward eta Kennedy, 1999; Ward et al., 2001) eta distantzia kultural handiagoa duten pertsonek pairatzen dituzten bazterketak eta diskriminazioak zailtzen dutela egokitzapen-prozesua (Nesdale eta Mak, 2003; Prilleltensky, 2008). Baina ez dute konfirmatzen emakumeen zaurgarritasun handiagoa (Standing, 2000; Aroian et al., 2003), ezin delako demostratu emakumeek arazo sozioekonomiko eta legal gehiago dutenik (Elgorriaga et al., 2016; Standing, 2000) eta diskriminazio handiagoa bakarrik aurkitzen delako Magrebeko emakumeetan.

\section{Ongizatea eta estresa adierazten dituzten faktoreak}

Bigarren helburua magrebtarren eta latinoamerikarren estresa eta ongizatea aurreikusten dituzten faktoreak definitzea izan zen. Ikus daiteke ongizatea azaltzen duten faktoreak aldakorrak direla talde batetik bestera; aldiz, estresaren faktoreak nahiko antzekoak dira bi populazioetan. Estresa azaltzeko, emaitzek azpimarratzen dituzten faktoreek aldagai material-ekonomikoei eta babes sozialari aipamena egiten diete, non pertsonek egoera estresagarriei aurre egiteko erabiltzen dituzten tresna edo ezaugarriek taldearen arabera berezitasun batzuk azaltzen dituzten 
(Folkman eta Lazarus, 1980). Horrela, magrebtar biztanlerian nabarmena da bertako biztanleriaren laguntza, hautemandako diskriminazioa eta laguntza sozialaren beharra. Latinoamerikako biztanlerian, berriz, hiru aldagai horiei autonomia soziala, bizilekua hobetzearen beharra eta familiakide gehiago alboan izatea gehitzen zaizkie. Datu hauek berresten dute estresaren aldagai azaltzaile bezala errekurtso sozioekomikoen garrantzia (Jasinskaja-Lahti et al., 2006; Singhammer eta Bancila, 2011), edota bizileku bat aurkitu beharrak dakarren tentsioa; prekarietatea, pilaketa, osasun eza edo immigranteek pairatzen dituzten gehiegizko prezioak gehituaz (Achotegui, 2008; Hovey eta Magaña, 2000). Hala eta guztiz, bertako pertsonen laguntza (Smith eta Bond, 1993; Ward et al., 2001) eta familikideen gertutasuna (sostengua eta kontaktua kontuan hartuz) estresaren babesle garrantzitzuak direla baieztatzen da (Hovey eta Magaña, 2000). Azkenik, argi geratzen da Espainiako Estatuan (Patiño eta Kirchner, 2008), beste testuinguru batzuetan egindako ikerketekin batera (adibidez, Navara eta James, 2005; Ward et al., 2001), diskriminazioaren pertzepzioak bi populazioetan estresa aurresaten duela.

Ongizatea azaltzeko bi populazioetan amankomunean agertzen den aldagai bakarra haien jatorrizko herrialdeetako kideekin mantentzen duten kontaktua da (Neto, 2001), beraz ongizatearen eredu azaltzaileak ezberdinak dira populazio magrebtarrean eta latinoamerikarrean. Horrela, talde bakoitzaren ereduak prozesu migratzailearen ezaugarriekin daude lotuak: magrebtar populazioan lanaren botere azaltzailea baieztatzen da (Cuellar et al., 2004), familia gertu izatea, distantzia kulturala (Ward eta Kennedy, 1999), eta bizilekuaren beharrak (Neto, 1995). Latinoamerikar populazioan aldagai azaltzaileak dira behar soziala (Maslow, 1943), bertako populazioaren sostengua (Basabe et al., 2009; Hernández et al., 2004), formakuntza, adina eta lan-beharra (Cuellar et al., 2004). Emaitza hauetatik ondorioztatu eta baieztatzen da biztanleria migratzailearen ongizatea hein handi batean harrera-testuinguruan bizi izandako esperientziaren baitan dagoela. Horrek berresten du ezinbesteko ongizatea aurresateko aldagai psikosozialen nagusitasuna, aldagai soziodemografikoen aurrean (Hernández et al., 2005; Neto, 1995; Sam, 1998).

Emaitzok nabarmentzen dute etorkinen prozesu migratzailea eta osasun psikologikoa azaltzen dituzten egoerak talde batetik bestera aldakorrak izan daitezkeela. Ondorioz, esku-hartze psikosozialetako programak garatzeko garaian kontuan hartu behar da prozesu migratzaileko zailtasunetan prebenitzeko eta ongizate-mailak hobetzeko aldagaiak ezberdinak direla talde batetik bestera. Orokorrean, emaitza horiek adierazte dute ongizatearen ikuspegi ekologiko batetik lan egiteko beharra (Birman et al., 2005), non esku-hartze psikosozialak pertsonen autonomia pertsonal eta soziala garatzeko tresnak eskaini behar baititu, alde batera utzita esku-hartze asistentzialak. Era berean, ekintzak taldeetan egitea sustatzen da elkarrekintza soziala indartzeko eta ikerketa honetan aurki daitezkeen ongizatearen fenomeno moderatzaileak errazteko: kohesioa, sostengu soziala, gaitasun sozialen ikaskuntza, identitate amankomunaren sendotzea eta etorkizunaren itxaropena immigrazioaren zoritxarrei aurre egiteko. 


\section{Etorkinen ongizatea eta estres-maila bertako biztanleriarekin konparatuta}

Azkeneko helburuan aztertzen da ea biztanleria migratzaileak, Euskal biztanleriarekin alderatuz eta sexua kontuan hartuz, estres gehiago eta ongizate gutxiago duen. Datuek adierazi dute Magrebeko populazioak, Latinoamerikako eta bertako populazioarekin alderatuta, estres gehiago eta ongizate gutxiago adierazten duela. Emaitza hauek partzialki konfirmatzen dute hirugarren hipotesia, ikusi delako Magrebekoak estres eta ondoez gehiago duten pertsonak direla, baina ez dela aurkitu Latinoamerikako pertsonak bertako pertsonak baino okerrago egotea. Magrebeko taldea aztertzen denean, akulturazioaren estresaren hipotesiaren suposizioak konfirmatzen dira, etorkinek bertako pertsonek baino estres edo ondoez gehiago adierazten dutelako (Berry eta Sam, 1996). Emaitza hauek beste ikerketa batzuetan baieztatu dira (adibidez, Cuellar et al., 2004; Singhammer eta Bancilla, 2011). Aldi berean, kultur distantziaren suposizioen norabide berdinean doaz, hau da, distantzia handiagoa dagoenean zailtasun sozioekonomiko eta kultural gehiago, azaltzen dira, baita bazterketa-egoera gehiago ere (Nesdale eta Mak, 2003) eta horrekin estresa edo ondoez agertzeko probabilitatea handiagoa da (Ward et al., 2001). Lagina honetan konfirmatzen da Magrebeko pertsonek zailtasun gehiago dituztela eta latinoamerikarrek baino diskriminazio gehiago hautematen dutela. Bestetik, Latinoamerikako pertsonen egoera esplikatzeko egokiagoa da atzerritar osasuntsuaren paradoxaren hipotesia: defendatzen dute etorkinen osasuna bertakoenarekin konparatuta berdina edo hobea dela (Markides eta Coreil, 1986). Emaitza hauek babesten dute Sevillano eta lagunek (2013) aurkitu zutena testuinguru berdinean, baina osasun fisiko eta mentaleko neurriekin. Arlo psikologikoan ikusi zuten Kolonbiako pertsonen osasun mentala bertakoena bezalakoa zela, baina beste taldeek, horien artean magrebtarrek, osasun okerragoa zuten. Ondorio berdintsuetara ailegatu ziren Thapa et al. (2007) Norvegian egindako ikerketa batean, non etorkinen jatorriaren arabera hipotesi bat edo bestea konfirmatzen zen.

Azkenik, ez da aurkitu emakumeek gizonek baino estres eta ondoez gehiago adieraztea, laugarren hipotesian proposatzen genuen bezala. Emaitza hauek literaturan dauden ikerketa askoren kontra doaz (adibidez, Aroian et al., 2003; Patiño eta Kirchner, 2008; Solé, 2000;). Azpimarratu behar da gero eta lan gehiagok erakusten dutela bai gizonek bai emakumeek estres-maila berdina adierazten dutela (adibidez, Teixeira de Almeida eta Vaz, 2011; Lahoz eta Forns, 2013). Ikerketa batzuen arabera, emakumeek akulturazio-prozesuan estresaren hautemate handiagoa izaten dute jasan behar dituzten zailtasunengatik, hala eta guztiz ere, Euskal Herrian eginiko ikerketek (Elgorriaga et al., 2012; Sevillano et al., 2013) baieztatu dute emakume eta gizon etorkinen egoera sozioekonomikoa eta diskriminazio-pertzepzioa antzekoak direla eta horrek aditzera ematen du estresaren pertzepzioan desberdintasunik ez egotea. Bestetik, ondoezaren inguruan dauden ikerketetan kontraesanak daude: batzuek egiaztatu dute gizonek ongizate gehiago adierazten dutela (Cuellar et al., 2004; Neto, 2001), beste batzuek emakumeek gehiago dutela (Chen, Benet-Martínez eta Bond, 2008; Utsey eta Payne, 2000) eta beste batzuek ez dute desberdintasunik aurkitu (Hernández, Pozo eta Alonso, 2004; Van Selm, Sam eta Van Oudenhoven, 2002). Kasu horietan behatu da generoaren eragina aztertzen ari den kultur taldearen araberakoa dela, horrela, 
emakume magrebtarrek ongizate gehiago dute gizonekin alderatuz, baina biztaleria latinoamerikarrean edo bertakoan ez da ezberditansun estatistikoki esanguratsurik azaltzen emakume eta gizonen artean.

\section{Ikerlanaren mugak eta ikertzeko dauden ildoak}

Bukatzeko beharrezkoa da lan honen mugen kontzientzia izatea. Lehenik, lagina gure testuingurukoa izanik, zaila da emaitzak beste testuinguruetara zabaltzea. Hala ere, ikerketa honetan aurkitutako datuak erabilgarriak dira beste testuinguru soziokultural antzekoetan gertatzen dena ulertzeko. Bigarrenik, kulturaren eta sexuaren erregresio-analisiak ezin izan dira egin, lagina ez delako behar bezain handia. Hirugarrenik, interesgarria izango litzateke metodologia kuantitatiboa metodologia kualitatiboarekin osatzea, horrela, etorkinen egoera eta ongizatearen inguruan gehiago sakonduko litzateke. Azkenik, lagina lortzeko zailtasunen ondorioz, biztanleria immigrateen estres-maila alderatu egin da beste etorkin talde batekin edo bertako biztanleria talde batekin, beste ikerketa batzuetan egin den bezala (adibidez, Cuellar et al., 2004; Singhammer eta Bancilla, 2011). Hala eta guztiz ere, horrek ez du baimentzen migrazioa gertatu eta gero estres-maila haunditu, mantendu eta txikitu egiten denik. Zentzu horretan, egoera egokiena ikerketa longitudinalak egitea izango litzateke: migrazioan pre eta pots datuekin edo hori egin ezean lagina lortu jatorrizko herrialdeetan. Horrek lagunduko luke estresaren ulermenean eta prozesu migratorioarekin duen loturan sakontzeko.

Mugak alde batera utzita, ikerketa honen emaitzek agerian uzten dute nola pertsona immigranteen jatorri kulturalak eta generoak akulturazio-prozesua eta estres- eta ongizate-mailak baldintzatzen dituzten. Begi-bistan jartzen dute ere akulturazio-prozesuak eta bertako protagonistak ikertzen jarraitzeko beharra, ongizatearekin lotua dagoen analisiak duen aniztasun- eta konplexutasun-mailaren ondorioz, aldagai estruktural bezala generoa eta jatorri kulturala kontuan hartuz eta zeharkako bezala biztaleria immigranteak bizi dituen prozesu guztiak.

\section{Erreferentziak}

Achotegui, J. (2004): «Emigrar en situación extrema: el Síndrome del inmigrante con estrés crónico y múltiple (Síndrome de Ulises)», Norte de Salud Mental, 21, 39-52.

, (2008): «Migración y crisis: el síndrome del inmigrante con estrés crónico y múltiple (Síndorme de Ulises)», Avances en Salud Mental Relacional, 7, 1-22.

Amponsah, M.O. (2010): "Non UK university students stress levels and their coping strategies", Educational Research, 1, 88-98.

Arnoso, A.; Martínez-Taboada, C.; Elgorriaga, E. eta Otero, N. (2009): «Minorías culturales y representaciones: identidades y trayectorias socio comunitarias», in F. Cintrón Bou, E. Acosta Pérez, eta L. Díaz Mendez (ed.), Psicología Comunitaria: Interviniendo con comunidades en las Américas, Publicaciones Puertorriqueñas, Hato Rey, Puerto Rico, 303-322.

Aroian, K.J., Norris, A.E. eta Chiang, L. (2003): «Gender differences in psychological distress among immigrants from the former Soviet Union», Sex Roles, 48, 39-51, doi: 10.1023/A:1022392528490. 
Atienza, F.L., Pons, D., Balaguer, I. eta García-Merita, M. (2000): «Propiedades psicométricas de la escala de satisfacción con la vida en adolescentes», Psicothema, 12, 314319.

Baltatescu, S. (2005): «Subjective well-being of immigrants in Europe. A comparative study. European Identity and Free Movement of Persons in Europe. Oradea, Rumania», in L. Pop eta C. Matiuta (ed.), European Identity and Free Movement of Persons in Europe, University of Oradea Publishing House, Oradea, Rumania, 128-143.

Bartram, D. (2011): «Economic migration and happiness: comparing immigrants' and natives' happinness gains from income», Social Indicators Research, 103, 57-76, doi: 10.1007/s11205-010-9696-2.

Basabe, N.; Zlobina, A. eta Páez, D. (2004): «Integración sociocultural y adaptación psicológica de los inmigrantes extranjeros en el País Vasco», Cuadernos Sociológicos Vascos, 15, Gobierno Vasco, Vitoria-Gasteiz.

Basabe, N.; Páez, D., Aierdi, X. eta Jiménez-Aristizabal, A. (2009): «Salud e inmigración. Aculturación, bienestar subjetivo y calidad de vida. Ikuspegi. Inmigrazioaren euskal behatokia», Colección Ikusgai Bilduma, 3, Itxaropena, Zarautz.

Bergami, M. eta Bagozzi, R. (2000): «Self-categorization, affective commitment and group self-esteem as distinct aspects of social identity in the organization", British Journal of Social Psychology, 39, 555-577, doi: 10.1348/014466600164633.

Berry, J.W.; Kim, V.; Minde, T. eta Mok, D. (1987): «Comparative studies of acculturative stress", International Migration Review, 21, 491-511, doi: 10.2307/2546607.

Berry, J.W. eta Sam, D.L. (1996): «Acculturation and adaptation», in J.W. Berry, M.H. Senegall eta C. Kagitçibasi (ed.), Handbook of cross-cultural psychology. Social behaviour and application, Allyn \& Bacon, Boston, 291-326.

Berry, J.W. (1997): «Immigration, acculturation, and adaptation», Applied Psychology: An International Review, 46, 5-68, doi: 10.1111/j.1464-0597.1997.tb01087

, (2003): «Conceptual approaches to acculturation», in K. Chung, P. Balls-Organista era G. Marin (ed.), Acculturation: Advances in Theory, Measurement, and Applied Research, American Psychological Association, Washington, 17-37.

Birman, D.; Trickett, E. eta Buchanan, R. (2005): «A tale of two cities: Replication of a study on the acculturation and adaptation of immigrant adolescents from the Former Soviet Union in a different community context», American Journal of Community Psychology, 35, 83-101, doi: 10.1007/s 10464-005-1891-y.

Chen, S.X., Benet-Martínez, V. eta Bond, M.H. (2008): «Bicultural identity, bilingualism, and psychological adjustment in multicultural societies: immigration-based and globalization-based acculturation», Journal of Personality, 76, 803-837.

Cohen, S.; Kamarck, T. eta Mermelstein, R. (1983): «A global measure of perceived stress», Journal of Health and Social Behavior, 24, 385-396, doi:10.2307/2136404.

Cuellar, I.; Bastida, E. eta Braccio, S. M. (2004): «Residency in the United States, subjective well-being, and depression in an older Mexican-origin sample», Journal of Aging and Health, 16, 447-466, doi: 10.1177/0898264304265764.

Diener, E.; Emmons, R.A.; Larsen, R.J. eta Griffin, S. (1985): «The satisfaction with life scale», Journal of Personality Assessment, 49, 71-75.

Díez Nicolas, J. (2010): «Construcción de un índice de Xenofobia-Racismo», Ministerio del Ministerio de Trabajo e Inmigración, 80, 21-38.

Elgorriaga, E.; Arnoso, A.; Martínez-Taboada, C. eta Otero, N. (2012): «Proceso migratorio y ajuste psicológico de las mujeres latinoamericanas y magrebíes», Migraciones, 31, 125-154.

Elgorriaga, E.; Ibabe, I. eta Arnoso, A. (2014): «Psychosocial adjustment of Spanish emigrants and non-emigrants», Procedia - Social and Behavioral Sciences, 131, 382-385, doi: 10.1016/j.sbspro.2014.04.134 
Elgorriaga, E.; Ibabe, I. eta Arnoso, A. (2016). «Españoles que emigran a países de la Unión Europea: predictores de su ajuste psicológico», Revista de Psicología Social, 31, 332-351.

Finch, B.K. eta Vega, W.A. (2003): «Acculturation stress, social support, and self-rated health among Latinos in California», Journal of Immigrant Health, 5, 109-117.

Folkman, S. eta Lazarus, R.S. (1980): «An analysis of coping in a middle-aged community sample», Journal of Health and SocialBehavior, 21, 219-239, doi: 10.2307/2136617.

Gregorio, C. (1997): «El estudio de las migraciones internacionales desde la perspectiva del género", Migraciones, 1, 145-175.

Gregorio, C eta Ramírez, A (2000): «¿En España es diferente?: la inmigración femenina y los cambios en la concepción del trabajo», Papers. Revista de Sociología, 60, 257-273.

Hernández, S.; Pozo, C. eta Alonso, E. (2004): «Apoyo social y bienestar subjetivo en un colectivo de inmigrantes. ¿Efectos directos o amortiguadores?», Boletín de Psicología, 80, 79-96.

Hernández, S.; Pozo, C.; Alonso, E. eta Martos, J. M. (2005): «Estructura y funciones del apoyo social en un colectivo de inmigrantes marroquíes", Anales de Psicología, 21, 304-315.

Hovey, J.D. eta Magaña, C.G. (2000): «Acculturative stress, anxiety, and depression among Mexican immigrant farmworkers in the Midwest United States», Journal of Immigrant Health, 2, 119-131, doi: 10.1023/A:1009556802759.

Ikuspegi (2010): «Barómetro Ikuspegi: Percepciones y actitudes hacia la inmigración extranjera», Panorámica de la inmigración, 36, Immigrazioaren Euskal Behatokia.

INE Instituto Nacional de Estadística, (2014): Explotación estadística del Padrón de Inmigrantes residentes en España, <http://www.ine.es/prensa/np854.pdf> helbidetik berreskutatua.

, (2017): Explotación estadística del Padrón de Inmigrantes residentes en España, <http://www.ine.es/jaxi/Tabla.htm?path=/t20/e245/p04/provi/l0/\&file=0ccaa002. $p x>$ helbidetik berreskutatua.

Irfaeya, M.; Maxwell, A.E. eta Krämer, A. (2008): «Assessing psychological stress among Arab migrant women in the city of Cologne/Germany using the community oriented primary care (COPC) approach», Journal of Immigrant Minority Health, 10, 337-344.

Jasinskaja-Lahti, I.; Liebkind, K. eta Perhoniemi, R. (2006): «Perceived discrimination and well-being: a victim study of different immigrant groups», Journal of Community and Applied Social Psychology, 16, 267-284, doi: 10.1002/casp.865.

Lahoz, S. eta Forns, M. (2013): «Cuestionario de estrés percibido aplicado al proceso migratorio", Ansiedad y Estrés, 19, 27-39.

Lazarus, R.S. eta Folkman, S. (1984): Stress, appraisal and coping, Springer, New York.

Markides, K.S. eta Coreil, J. (1986): «The health of Hispanics in the southwestern United States: an epidemiologic paradox», Public health reports, 101, 253-265.

Martínez-Taboada, C.; Arnoso, A. eta Elgorriaga, E. (2006): Estudio del Choque Psicosocial de la población inmigrada a Donostia, Donostiako Udala, Donostia.

Maslow, A. (1943): «A theory of human motivation», Psychological Review, 50, 370-396.

Montero, M. (1996): «Identidad social negativa y crisis socioeconómica: Un estudio psicosocial», Revista Interamericana de Psicología, 30, 43-58.

Navara, G.S. eta James, S. (2005): «Acculturative stress of missionaries: Does religious orientation affect religious coping and adjustment?», International Journal of Intercultural Relations, 29, 39-58, doi: 10.1016/j.ijintrel.2005.04.004.

Navas, M.S. eta Cuadrado, I. (2003): «Actitudes hacia inmigrantes africanos y gitanos: un estudio comparativo", Apuntes de Psicología, 21, 29-49. 
Nesdale, D. eta Mak, A. (2003): «Ethnic identification, self-esteem and immigrant psychological health», International Journal of Intercultural Relations, 27, 23-40, doi: 10.1016/ S0147-1767(02)00062-7.

Neto, F. (1995): «Predictors of satisfaction with life among second generation migrants», Social Indicators Research, 35, 93-116.

(2001): «Satisfaction with life among adolescents from immigrant families in Portugal», Journal of Youth and Adolescence, 30, 53-67.

Organista, P.B.; Organista, K.C. eta Kurasaki, K. (2002): «The relationship between acculturation and ethnic minority mental health», in K.M. Chun, R.B. Organista, eta G. Marine (ed.), Acculturation: Advances in theory, measurement, and applied research, American Psychological Association, Washington, DC, 139-161.

Patiño, C. eta Kirchner, T. (2008): «Estrés y coping en inmigrantes latinoamericanos residentes en Barcelona», Revista Iberoamericana de psicología: Ciencia y Tecnología, 1, 29-38.

Prilleltensky, I. (2008): «The role of power in wellness, oppression, and liberation: the promise of psychopolitical validity», Journal of community psychology, 36, 116-136, doi: 10.1002/jcop.20225.

Remor, E. eta Carrobles, J.A. (2001): «Versión Española de la escala de estrés percibido (PSS-14): Estudio psicométrico en una muestra VIH+», Ansiedad y Estrés, 7, 195201.

Sam, D.L. (1998): «Predicting life satisfaction among adolescents from immigrant families in Norway", Ethnicity and Health, 3, 5-18.

Sevillano, V.; Basabe, N.; Bobowik, M. eta Aierdi, X. (2013): «Health-related quality of life, ethnicity and perceived discrimination among immigrants and natives in Spain», Ethnicity and Health, 19(2), 178-197, doi:10.1080/13557858.2013.797569.

Singhammer, J. eta Bancila, D. (2011): «Associations between stressful events and selfreported mental health problems among non-western immigrants in Denmark», Journal of Immigrant Minority Health, 13, 371-378, doi: 10.1007/s10903-0099281-4.

Smith, P.B. eta Bond, M.H. (1993): Social psychology across cultures, Harvester Wheatsheaf, New York.

Solé, C. (2000): «Inmigración interior e inmigración exterior», Papers, 60, 211-224.

Standing, H. (2000): «Gender: A missing dimension in human resource policy and planning for health reforms", Human Resources for Health Development Journal, 4, 27-42.

Tajfel, H. eta Turner, J.C. (1979): «An integrative theory of inter-group conflict», in W.G. Austin eta S. Worchel (ed.), The social psychology of intergroup relations, Brooks/ Cole, Monterey, CA, 33-47.

Taylor, S.J. eta Bogdan, R. (1986): Introducción a los métodos cualitativos de investigación, Paidós, Buenos Aires.

Teixeira de Almeida, A.P. eta Vaz, A. (2011): «Vulnerability to stress in migratory contexts: a study with Eastern European immigrants residing in Portugal», Journal of Immigrant Minority Health, 13, 690-696, doi: 10.1007/s10903-011-9451-z.

Thapa, S.B.; Daalgard, O.S.; Claussen, B.; Sandvick, L. eta Hauff, E. (2007): «Psychological distress among immigrants from high- and low-income countries: findings from the Oslo Health Study», Nordic Journal of Psychiatry, 61, 459-465, doi: 10.1080/08039480701773261.

Utsey, S.O. eta Payne, Y.A. (2000): «Differential psychological and emotional impacts of facerelated stress», Journal of African American men, 5, 56-72.

Van Selm, K.; Sam, D.L. eta Van Oudenhoven, J.P. (2002): «Life satisfaction and competente of Bosnian refugees in Norway», Scandinavian Journal of Psychology, 38, 143-149. 
Vega, W.A.; Kolody, B.; Aguilar-Gaxiola, S.; Alderete, E.; Catalano, R. eta Caraveo-Anduaga, J. (1998): «Lifetime prevalence of DSM-III-R psychiatric disorders among urban and rural Mexican Americans in California», Archives of General Psychiatry, 55, 771-778.

Vergara, A.I. eta Balluerka, N. (2000): «Metodología en la investigación transcultural: perspectivas actuales», Psicothema, 12, 557-562, doi: 10.1007/s10903-0119451-z.

Ward, C. eta Kennedy, A. (1999): «The measurement of sociocultural adaptation», International Journal of Intercultural Relations, 23, 659-677, doi: 10.1016/S01471767(99)00014-0.

Ward, C.; Bochner, S. eta Furnham, A. (2001): The psychology of culture shock, Routledge, Hove, UK.

Ward, C. eta Kagitcibasi, C. (2010): «Applied acculturation research: working with, for, and beyond communities», International Journal of Intercultural Relations, 34, 186189, doi: 10.1016/j.ijintrel.2010.02.002.

WHO (2010): How health systems can address health inequalities linked to migration and ethnicity, Copenhagen, WHO Regional Office for Europe, <http://www.euro.who. int/_data/assets/pdf_file/0005/127526/e94497.pdf>.

Wittig, U.; Lindert, J.; Merbach, M. eta Brähler, E. (2008): «Mental health of patients from different cultures in Germany», European Psychiatry, 1, 28-35, doi: 10.1016/ S0924-9338(08)70059-2.

Zlobina, A.; Basabe, N.; Páez, D. eta Furnham, A. (2006): «Sociocultural adjustment of immigrants: universal and group-specific predictors», International Journal of Intercultural Relations, 30, 195-211. 

